\title{
Effects of corn-based reduced-starch diets using alternative carbohydrate sources on performance of lactating Holstein cows
}

\author{
H. M. Dann, ${ }^{* 1}$ S. M. Fredin, ${ }^{*}$ K. W. Cotanch, ${ }^{*}$ R. J. Grant, ${ }^{,}$C. Kokko, ${ }^{*}$ P. Ji, ${ }^{*}$ and K. Fujita† \\ *William H. Miner Agricultural Research Institute, Chazy, NY 12921 \\ †Zen-Noh National Federation of Agricultural Cooperative Associations, Tokyo 100-6832, Japan
}

\begin{abstract}
Increases in grain prices have led to renewed interest in feeding reduced-starch diets to lactating dairy cows. An experiment was conducted to determine the effects of altering carbohydrate sources and reducing dietary starch on lactational performance, feeding behavior, and ruminal measures of Holstein dairy cows. Fifteen multiparous cows (6 ruminally cannulated) were blocked and assigned to 1 of 5 squares and used in a replicated $3 \times 3$ Latin square design with $21-d$ periods. Cows were fed 1 of 3 experimental diets: a control diet containing $20 \%$ brown midrib corn silage, $20 \%$ conventional corn silage, and $10 \%$ hay crop silage $(\mathrm{CON})$; a reduced-starch high-forage diet containing $53 \%$ brown midrib corn silage and $10 \%$ hay crop silage (HFOR); and a reduced-starch diet containing the same forages as CON with partial replacement of corn meal by nonforage fiber sources (HNFFS). The CON diet contained (\% of dry matter) $26.0 \%$ starch and $34.7 \%$ neutral detergent fiber (NDF), whereas the HFOR and HNFFS diets contained 21.4 or $21.3 \%$ starch and 38.3 or $38.0 \%$ NDF, respectively. Dry matter intake tended to be greater for cows fed the CON diet $(28.2 \mathrm{~kg} / \mathrm{d})$ compared with those fed the HFOR diet $(27.2 \mathrm{~kg} / \mathrm{d})$. Dry matter intake for cows fed the HNFFS diet was intermediate $(27.7 \mathrm{~kg} / \mathrm{d})$. Milk yield was greater for cows fed the CON diet $(51.6 \mathrm{~kg} / \mathrm{d})$ compared with those fed the HFOR diet $(48.4 \mathrm{~kg} / \mathrm{d})$, but milk fat content tended to increase for cows fed the HFOR diet (3.98\%) compared with those fed the CON diet (3.66\%). Consequently, fat-corrected and solids-corrected milk yields were unaffected by dietary treatments. Total chewing, eating, and rumination times were similar across all dietary treatments. Rumination time per kilogram of DM was greatest for the HFOR diet, intermediate for the HNFFS diet, and least for the CON diet, whereas rumination time per kilogram of NDF was greatest for the CON diet and least for the HNFFS diet. Mean
\end{abstract}

Received November 6, 2014

Accepted March 8, 2015.

${ }^{1}$ Corresponding author: Dann@whminer.com ruminal $\mathrm{pH}, \mathrm{NH}_{3}-\mathrm{N}(\mathrm{mg} / \mathrm{dL})$, and total volatile fatty acid concentrations $(\mathrm{m} M)$ were similar across all dietary treatments. Molar proportion of ruminal acetate (mol/100 mol) was increased for cows fed the HFOR diet compared with cows fed the CON diet. Microbial $\mathrm{N}$ yield measured by urinary purine derivatives was unaffected by dietary treatment. Reduced-starch diets containing greater amounts of high quality, highly digestible forage or nonforage fiber sources in place of corn meal resulted in similar fat-corrected or solidscorrected milk yield for high-producing dairy cows in the short term.

Key words: feeding behavior, lactation, ruminal measures, starch

\section{INTRODUCTION}

Corn grain prices have trended higher over the past several years, and projections are for continued higher priced corn in the future (USDA-NASS, 2014). Consequently, formulating reduced-starch diets has become more economical. Common strategies for reducing dietary starch include the partial replacement of grain with highly digestible forage such as corn silage or a nonforage fiber source such as beet pulp, soybean hulls, or wheat middlings. Because both dietary formulation approaches could be economical, depending on the cost of the forage or nonforage fiber sources compared with corn grain, it is important to directly compare the responses of cows fed reduced-starch diets based on either strategy with diets containing more traditional amounts of starch (25 to $30 \%$ of DM).

Reducing dietary starch and increasing physically effective fiber in lactating dairy cow diets can have positive effects on ruminal health by increasing rumination, saliva flow, buffering capacity, and ruminal pH (Allen, 1997; Mertens, 1997). Previous studies have evaluated the partial replacement of corn meal with corn silage (Dann et al., 2008; Agle et al., 2010; Weiss et al., 2011) or nonforage fiber sources (Voelker and Allen, 2003a; Ferraretto et al., 2011; Dann et al., 2014). In these studies, reducing dietary starch using either formulation strategy consistently resulted in similar FCM yields 
with minor or no change in feed efficiency compared with normal-starch diets. However, direct comparisons of the effects of normal-starch compared with reducedstarch diets using both formulation strategies within the same study are limited.

The objectives of this experiment were to compare the effects of feeding a normal-starch diet with reducedstarch diets where corn meal was replaced with a highly digestible forage or nonforage source of fiber. Measurements of interest were lactational performance, feeding behavior, and ruminal measures of Holstein dairy cows. We hypothesized that these reduced-starch diets would result in similar FCM yield, improved milk fat yield, increased rumination time, and increased ruminal $\mathrm{pH}$ compared with a normal-starch diet.

\section{MATERIALS AND METHODS}

\section{Experimental Design, Diets, and Management of Cows}

This experiment was conducted at the William $\mathrm{H}$. Miner Agricultural Research Institute (Chazy, NY) from September 16 to November 18, 2011. All procedures involving animals were approved by the William H. Miner Agricultural Research Institute Animal Care and Use Committee. Fifteen multiparous cows (6 ruminally cannulated) were blocked and assigned to 1 of 5 squares by ruminal fistulation status, DIM, and preexperiment milk yield and used in a replicated $3 \times 3$ Latin square design with 21-d periods with all squares conducted concurrently. The first $14 \mathrm{~d}$ served as the dietary adaptation period and the last $7 \mathrm{~d}$ served as the collection period. Cows were (mean \pm SD) $711 \pm$ $87 \mathrm{~kg}$ of BW, $103 \pm 24 \mathrm{DIM}$, and $2.7 \pm 1.1$ parities at the beginning of the experiment.

Three diets were formulated to contain varying concentrations of digestible NDF through use of brown midrib (BMR) corn silage, conventional corn silage, and hay crop silage. The 3 dietary treatments (Table 1; DM basis) were (1) a control diet containing $50 \%$ forage composed of $20 \%$ conventional corn silage, $20 \%$ BMR corn silage, and $10 \%$ hay crop silage $(\mathbf{C O N})$; (2) a high-forage diet containing $63 \%$ forage composed of $53 \%$ of the same BMR corn silage and $10 \%$ of the same hay crop silage (HFOR); and (3) a diet containing $50 \%$ forage composed of the same forages as the control diet, but with partial replacement of corn meal and soybean meal with nonforage fiber sources including beet pulp, wheat middlings, and dried distillers grains plus solubles (HNFFS). Soybean meal was reduced in the HFOR and HNFFS diets to ensure that all diets were isonitrogenous. The CON diet was formulated to contain (\% of DM) $31 \%$ NDF and $27 \%$ starch, the HFOR diet was formulated to contain $35 \%$ NDF and $20 \%$ starch, and the HNFFS diet was formulated to contain 36\% NDF and 20\% starch. Diets were formulated with the CPM-Dairy nutrition model (version 3.0; Cornell University, Ithaca, NY; University of Pennsylvania, Philadelphia, PA; William H. Miner Agricultural Research Institute, Chazy, NY). The cow description used for formulation was a multiparous (second lactation) cow 103 DIM with a BCS of 3.00, BW of $710 \mathrm{~kg}$, DMI of $27.2 \mathrm{~kg} / \mathrm{d}$, and milk yield of 50.3 $\mathrm{kg} / \mathrm{d}$ containing $3.8 \%$ fat and $3.1 \%$ true protein. The model-predicted MP was 3,075, 2,978, and $3,007 \mathrm{~g} / \mathrm{d}$ for the CON, HFOR, and HNFFS diets, respectively.

Cows were housed in a tiestall barn equipped with mattresses, individual feed boxes, and individual water bowls. Cows were fed for ad libitum intake (target of $5 \%$ orts) once daily at $1500 \mathrm{~h}$, and feed was pushed up at $0700 \mathrm{~h}$. The dietary treatments were prepared in a Calan Data Ranger (American Calan Inc., Northwood, $\mathrm{NH})$. Cows were milked 3 times daily $(0430,1230$, and $2030 \mathrm{~h}$ ) in a double-12 parallel milking parlor (Xpressway Parallel Stall System; BouMatic, Madison, WI).

\section{Data Collection, Sampling Procedures, and Analytical Methods}

Individual feed ingredients were collected weekly and dried in a forced-air oven at $105^{\circ} \mathrm{C}$ for 18 to $24 \mathrm{~h}$ for DM determination. Diets were adjusted for changes in DM content of the feed ingredients when a feed ingredient $\mathrm{DM}$ value was outside the range of the $\mathrm{DM}$ mean \pm 1.2 standard deviations or when a new feed ingredient source was used. Feed ingredients were also collected daily from d 15 to 21 , and a portion of each sample was dried in a forced-air oven at $105^{\circ} \mathrm{C}$ for 18 to $24 \mathrm{~h}$ for $\mathrm{DM}$ determination. The remaining portion of each sample collected was frozen at $-20^{\circ} \mathrm{C}$ and then composited by period on an equal-volume basis for chemical analysis.

Composites of feed ingredients and diets were analyzed for chemical composition by a commercial laboratory (Cumberland Valley Analytical Services Inc., Hagerstown, MD). Analyses included DM, OM (method 942.05; AOAC International, 2012), CP (method 990.03; AOAC International, 2012), soluble protein according to Krishnamoorthy et al. (1982), fat (method 2003.05; AOAC International, 2012), ADF (method 973.18; AOAC International, 2012), NDF using $\alpha$-amylase but excluding sodium sulfite (Van Soest et al., 1991), ADL (Goering and Van Soest, 1970), starch according to Hall (2009), and minerals (method 985.01; AOAC International, 2012). Sugar was determined as described by Hall et al. (1999) with modifications. Sugar was measured as ethanol-soluble carbohydrates after a 2-h extraction with 80:20 ( $\mathrm{vol} / \mathrm{vol}$ ) ethanol/water while ag- 
Table 1. Ingredient composition (DM basis) of the diets varying in carbohydrate source

\begin{tabular}{|c|c|c|c|}
\hline \multirow[b]{2}{*}{ Item } & \multicolumn{3}{|c|}{ Treatment $^{1}$} \\
\hline & $\mathrm{CON}$ & HFOR & HNFFS \\
\hline Conventional corn silage & 19.98 & - & 19.99 \\
\hline Brown midrib corn silage & 19.98 & 53.32 & 19.99 \\
\hline Hay crop silage & 9.99 & 10.00 & 10.00 \\
\hline Corn meal & 14.99 & - & 3.75 \\
\hline Pelleted beet pulp & 5.00 & 5.00 & 10.83 \\
\hline \multicolumn{4}{|l|}{ Grain mix } \\
\hline Soybean meal & 8.33 & 6.66 & 3.75 \\
\hline Wheat middlings & 5.00 & 5.00 & 10.83 \\
\hline Distillers dried grains with solubles & - & 3.33 & 4.17 \\
\hline Canola meal & 6.66 & 6.66 & 6.66 \\
\hline AminoPlus $^{2}$ & 4.33 & 4.33 & 4.33 \\
\hline Molasses & 1.25 & 1.25 & 1.25 \\
\hline Mixer fat & 0.92 & 0.76 & 0.76 \\
\hline Dextrose & 0.67 & 0.67 & 0.67 \\
\hline Rumen inert fat & 0.48 & 0.48 & 0.48 \\
\hline Calcium carbonate & 1.15 & 1.15 & 1.15 \\
\hline Sodium sesquicarbonate $^{3}$ & 0.61 & 0.71 & 0.71 \\
\hline Salt & 0.37 & 0.37 & 0.37 \\
\hline Smartamine $\mathrm{M}^{4}$ & 0.06 & 0.06 & 0.06 \\
\hline Magnesium oxide & 0.10 & 0.10 & 0.10 \\
\hline Trace minerals ${ }^{5}$ & 0.03 & 0.03 & 0.03 \\
\hline Organic trace minerals ${ }^{6}$ & 0.03 & 0.03 & 0.03 \\
\hline Selenium, inorganic ${ }^{7}$ & 0.02 & 0.02 & 0.02 \\
\hline Selenium, organic ${ }^{7}$ & 0.02 & 0.02 & 0.02 \\
\hline Vitamin $\mathrm{E}^{8}$ & $<0.01$ & $<0.01$ & $<0.01$ \\
\hline Vitamins $\mathrm{A}, \mathrm{D}$, and $\mathrm{E}^{9}$ & 0.03 & 0.03 & 0.03 \\
\hline Biotin 1\% & 0.01 & 0.01 & 0.01 \\
\hline
\end{tabular}

${ }^{1} \mathrm{CON}=$ normal-starch diet containing $50 \%$ forage HFOR $=$ lowstarch diet containing $63 \%$ forage; HNFFS = low-starch diet containing $50 \%$ forage composed of forages similar to the control diet with corn meal and soybean meal partially replaced by nonforage fiber sources.

${ }^{2} \mathrm{Ag}$ Processing Inc. (Omaha, NE).

${ }^{3}$ S-Carb (FCM Industrial Chemical Group, Philadelphia, PA).

${ }^{4}$ Adisseo (Alpharetta, GA).

${ }^{5} 1100$ Dairy TM; contained $0.02 \% \mathrm{Ca}, 18.82 \% \mathrm{~S}, 153,737 \mathrm{mg}$ of $\mathrm{Zn} /$ $\mathrm{kg}, 30,303 \mathrm{mg}$ of $\mathrm{Cu} / \mathrm{kg}, 136,364 \mathrm{mg}$ of $\mathrm{Mn} / \mathrm{kg}, 3,384 \mathrm{mg}$ of $\mathrm{Co} / \mathrm{kg}$, and $3,030 \mathrm{mg}$ of $\mathrm{I} / \mathrm{kg}$.

${ }^{6}$ Contained $51,633 \mathrm{mg}$ of $\mathrm{Zn} / \mathrm{kg}, 17,959 \mathrm{mg}$ of $\mathrm{Cu} / \mathrm{kg}, 28,571 \mathrm{mg}$ of $\mathrm{Mn} / \mathrm{kg}$, and $3,673 \mathrm{mg}$ of $\mathrm{Co} / \mathrm{kg}$.

${ }^{7}$ Contained $606 \mathrm{mg}$ of $\mathrm{Se} / \mathrm{kg}$ and $36.36 \% \mathrm{Ca}$.

${ }^{8}$ Contained 44,647 IU of vitamin E/ $\mathrm{kg}$.

${ }^{9}$ Contained $30,497 \mathrm{kIU}$ of vitamin $\mathrm{A} / \mathrm{kg}, 5,868 \mathrm{kIU}$ of vitamin $\mathrm{D} / \mathrm{kg}$, and $93,997 \mathrm{IU}$ of vitamin $\mathrm{E} / \mathrm{kg}$.

itated at room temperature. Fermentation analysis was performed on the ensiled forage composite samples by Cumberland Valley Analytical Services Inc. A 25-g wet sample was diluted with $200 \mathrm{~mL}$ of $\mathrm{H}_{2} \mathrm{O}$, blended, and filtered through 20 - to $25-\mu \mathrm{m}$ filter paper. Extract was used to determine $\mathrm{pH}$ with a Mettler DL12 $\mathrm{pH}$ Titrator (Mettler-Toledo LLC, Columbus, $\mathrm{OH}$ ) and $\mathrm{NH}_{3}-\mathrm{N}$ in a 1:3 ratio of extract and $\mathrm{H}_{2} \mathrm{O}$ with a Labconco Rapidstill II model 65200 analyzer (Labconco, Kansas City, MO). Lactic acid was determined in a 1:1 ratio of extract and deionized $\mathrm{H}_{2} \mathrm{O}$ with a YSI 2700 Select Biochemistry
Analyzer (YSI Inc., Yellow Springs, OH). Concentrations of acetic, propionic, butyric, and isobutyric acids were determined with a Perkin Elmer AutoSystem gas chromatograph using a Restek column packed with Stabilwax-DA (Perkin Elmer, Shelton, CT).

Forage and diet composite samples were used to determine particle size distribution on an as-fed basis using the Penn State Particle Separator (Lammers et al., 1996) and to determine particle size distribution on a DM basis $\left(55^{\circ} \mathrm{C}\right.$ ) by dry vertical sieving (Ro-Tap testing sieve shaker model B; W. S. Tyler Combustion Engineering Inc., Mentor, OH) with 19.00-, 13.20-, 9.50-, 6.70-, 4.75-, 3.35-, 2.36-, 1.18-, 0.60-, and 0.30-mm sieves for $10 \mathrm{~min}$. The physical effectiveness factor (pef) was determined by the standard dry vertical sieving method for feed ingredients and diets (Mertens, 2002). Physically effective neutral detergent fiber (peNDF) of a feed ingredient or diet was calculated as the product of its NDF content and its pef (Mertens, 1997).

In vitro NDF digestibility (24-h) of forage and diet composite samples (1-mm grind; Wiley mill, Arthur H. Thomas, Philadelphia, PA) was determined using an in vitro fermentation (Daisy ${ }^{\mathrm{Il}}$ Incubator, Ankom Technology Corp., Fairport, NY) in buffered medium containing ruminal fluid (Goering and Van Soest, 1970). Neutral detergent fiber with residual ash, using $\alpha$-amylase and sodium sulfite, was determined by the Ankom A200 Fiber Analyzer filter bag technique (Ankom Technology Corp.; Van Soest et al., 1991). In vitro digestibility of starch (2- and 7-h) of composite samples of corn silages, grain mixes, and diets (4-mm grind; Wiley mill) was determined by Cumberland Valley Analytical Services Inc. according to Richards et al. (1995).

Body weight was measured (Allweigh computerized scale; Allweigh Scale System Inc., Red Deer, AB, Canada) and BCS was assigned in 0.25-unit increments on a 1 to 5 scale (Ferguson et al., 1994) for each cow after the $1230 \mathrm{~h}$ milking on the day before the beginning of the study and on d 21 of each period.

Dry matter intake was determined by recording feed offered and refused on d 15 to 21 for each cow during each period. Samples of diets and orts were collected daily from d 15 to 21 , and a portion of each sample was dried in a forced-air oven at $105^{\circ} \mathrm{C}$ for 18 to $24 \mathrm{~h}$ for DM determination.

Milk yields were recorded (ProVantage Information Management System, Bou-Matic) at every milking during d 15 to 21 of each period and used to calculate average daily yield. Milk samples from 3 consecutive milkings per day for each cow were collected on d 18 and 19 of each test period and were preserved (Bronolab-W II Liquid Preservative; D\&F Control Systems Inc., Dublin, CA). Samples were sent to a commercial 
laboratory (Dairy One, Ithaca, NY) and analyzed for fat, true protein, lactose, SNF, urea N (method 972.16; AOAC International, 2012), and somatic cells by infrared procedures (Foss 4000; Foss Technology, Eden Prairie, MN). Samples were mathematically composited by day in proportion to milk yield at each sampling. Somatic cell count was transformed and analyzed as SCS according to Shook (1993) using the equation SCS $=\log _{2}(\mathrm{SCC} / 100)+3$, where SCC is in units of 1,000 cells/mL. Milk yield (average of d 15 to 21) and fat and SNF yields (average of d 18 and 19) were used to calculate $3.5 \% \mathrm{FCM}$ using the equation: $3.5 \% \mathrm{FCM}=$ $[(0.432 \times \mathrm{kg}$ of milk yield $)+(16.216 \times \mathrm{kg}$ of fat yield $)]$; and SCM using the equation $\mathrm{SCM}=[(12.3 \times \mathrm{kg}$ of fat yield $)+(6.56 \times \mathrm{kg}$ of SNF $)-(0.0752 \times \mathrm{kg}$ of milk yield)] according to Tyrrell and Reid (1965).

Feed efficiency $(\mathrm{kg} / \mathrm{kg})$ was calculated and expressed as actual milk/DMI, 3.5\% FCM/DMI, and SCM/DMI for d 15 through 21 of each test period. Milk N efficiency was calculated as ( $\mathrm{kg}$ of milk $\mathrm{N} / \mathrm{kg}$ of $\mathrm{N}$ intake) $\times 100$.

Cows were visually monitored for chewing activity (eating or ruminating) every 5 min for 3 consecutive 24-h periods (d 18 through 20) for each period. Chewing observations continued while cows were out of the tiestall barn for milking. Measurements over the $3 \mathrm{~d}$ were averaged to yield one 24 -h value per cow each period.

Ruminal $\mathrm{pH}$ was measured in 6 ruminally cannulated cows with an indwelling ruminal $\mathrm{pH}$ measurement system (Penner et al., 2006; LRCpH; Dascor, Escondido, CA) at 30-s intervals for a 72-h period on d 18 through 20. Ruminal $\mathrm{pH}$ measurements were averaged over a 5-min period. Ruminal $\mathrm{pH}$ data were summarized as mean $\mathrm{pH}$, minimum $\mathrm{pH}$, maximum $\mathrm{pH}$, the area of the curve below a $\mathrm{pH}$ of 5.5 and 5.8 , and time that $\mathrm{pH}$ was below 5.5 or 5.8 (Bauer et al., 1995; Dohme et al., 2008).

Samples of ruminal fluid (approximately $250 \mathrm{~mL}$ ) were collected from beneath the ruminal digesta mat at 4-h intervals for $24 \mathrm{~h}$ on d 18 (1430 h) and d 19 (1830, 2230, 0230, 0630, and 1030 h) of each period. Samples were strained though 4 layers of cheesecloth. The $\mathrm{pH}$ of ruminal fluid was determined immediately following collection after the sample was strained through cheesecloth. A portion of each sample of ruminal fluid (approximately $40 \mathrm{~mL}$ ) was frozen and stored at $-20^{\circ} \mathrm{C}$ until analysis of VFA concentration (Bulletin 856B; Supelco Inc., Bellefonte, PA). Ten milliliters of ruminal fluid was added to $100 \mu \mathrm{L}$ of $\mathrm{HCl}$ and frozen at $-20^{\circ} \mathrm{C}$ for analysis of ruminal $\mathrm{NH}_{3}-\mathrm{N}$ concentration (Chaney and Marbach, 1962). Volatile fatty acid concentration was determined by GC with a Varian CP-3800 gas chromatograph (Varian Inc., Palo Alto, CA) equipped with a flame-ionization detector and a 80/120 Carbopack B-DA/4\% Carbowax 20M column (Supelco Inc., Bellefonte, PA). Individual VFA were reported as molar proportions (mol/100 mol of total VFA).

Urinary excretion of purine derivatives (allantoin and uric acid) was used to estimate microbial $\mathrm{N}$ supply according to Valadares et al. (1999). Microbial N supply was estimated on d 18 and 19 of each period. A minimum of $40 \mathrm{~mL}$ of urine was collected between 3.5 and $4.5 \mathrm{~h}$ postfeeding by manual stimulation of the vulva. A 1-mL aliquot of urine was diluted immediately with $9 \mathrm{~mL}$ of $0.036 \mathrm{~N} \mathrm{H}_{2} \mathrm{SO}_{4}$ and stored at $-20^{\circ} \mathrm{C}$ for later analysis of allantoin (Chen et al., 1990). A 3-mL aliquot of urine was shipped overnight chilled on ice packs to the Animal Diagnostic Center at Cornell University (Ithaca, NY) for analysis of creatinine (creatinine kit; Roche Diagnostics Corp., Indianapolis, IN) and uric acid (uric acid plus kit; Roche Diagnostics Corp.) using a chemistry analyzer (Hitachi 917; Roche Diagnostics Corp.).

\section{Statistical Analysis}

Statistical analysis was performed using SAS software (version 9.2; SAS Institute Inc., Cary, NC). Data from the analysis of feed ingredients and diets were analyzed using the MEANS procedure of SAS ( $\mathrm{n}=3$ per feed ingredient and diet). The data were reported as descriptive statistics (mean \pm standard error).

The experiment was conducted and analyzed as a Latin square design. Data were subjected to ANOVA using the MIXED procedure of SAS. Fixed effects were treatment, period, and square; cow within square was the random effect. Ruminal measures were analyzed as repeated measures. The model included the fixed effects of treatment, period, square, time, and the interaction of treatment and time; cow within square was the random effect. Least squares means from the ANOVA results were separated using the Tukey procedure when the $F$-test had $P \leq 0.10$ to allow for evaluation of treatment differences when tendencies were detected. For repeated measures, treatment means within time point were compared using the SLICE option. Significance was declared at $P \leq 0.05$ and tendencies at $0.05<P$ $\leq 0.10$.

Data from 1 cow assigned to the HFOR treatment during period 1 were not included in the analyses because the cow had Klebsiella mastitis during the period; data from periods 2 and 3 were used. Data from another cow assigned to the HFOR treatment during period 3 were not included in the analyses due to a locomotion injury; data from periods 1 and 2 were used. 


\section{RESULTS AND DISCUSSON}

\section{Dietary and Ingredient Nutrient Composition}

Chemical composition of the dietary ingredients is presented in Table 2 . The 24 -h in vitro NDF digestibility was $46.2 \%$ for the BMR corn silage and $39.8 \%$ for the conventional corn silage. Content of $\mathrm{CP}$ was $7.4 \%$ for the BMR corn silage and $6.0 \%$ for the conventional corn silage and starch content was $35.8 \%$ for the BMR corn silage and $36.9 \%$ for conventional corn silage.

Chemical composition of the dietary treatments is in Table 3. All diets contained similar DM and CP contents. The HFOR and HNFFS diets contained numerically less starch than the CON diet $($ mean $=21.4 \%$ compared with $26.0 \%$ ); consequently, NDF content was $34.7 \%$ for the CON diet and averaged $38.0 \%$ for the HFOR and HNFFS diets. The 24-h NDF digestibility of the diets was $54.1 \%$ for CON, $53.0 \%$ for HFOR, and $51.6 \%$ for HNFFS. Given the ingredient composition of the diets (Table 1), the digestible NDF presumably came from a combination of forage and concentrate feeds in the CON diet, primarily from forage in the HFOR diet, and primarily from forage and nonforage fiber sources in the HNFFS diet.

Particle size distribution of the dietary ingredients is in Table 4. The particle size distributions of the conventional and BMR corn silages were numerically similar when assessed using the Penn State Particle Separator. As a result, the pef values calculated from dry sieving and as-fed data were nearly identical between the 2 silages (0.92 and 0.95 for conventional compared with 0.91 and 0.95 for BMR corn silage). The peNDF content was $38.7 \%$ for conventional corn silage and $37.6 \%$ for BMR corn silage. The hay crop silage contained more long particles retained on the top screen of the Penn State Particle Separator (15.6\%) than either of the corn silages, but the hay crop silage pef was 0.73 , resulting in a peNDF of $44.2 \%$. In general, the nonforage fiber sources and grain mixes were low in pef $(<0.20)$ with the exception of beet pulp, which had a pef of 0.98 , reflecting that the beet pulp had been pelleted and therefore was retained on the $1.18-\mathrm{mm}$ screen when dry sieved.

Particle size distribution of the diets is in Table 5 . The as-fed particle size distributions were similar for the CON and HNFFS diets, but the HFOR diet contained more medium-length particles. These distributions were expected because the CON and HNFFS diets were formulated to contain equivalent amounts of forage of similar particle size, whereas the HFOR diet contained 13 percentage units more forage. The pef was 0.58 for the CON diet, 0.62 for the HNFFS diet, and 0.68 greatest for the HFOR diet. The pelleted beet pulp in the
HNFFS diet likely resulted in the numerical increase in pef between the CON and HNFFS diets. The resulting peNDF content was $18.5 \%$ for the CON diet, $22.2 \%$ for the HNFFS diet, and $25.9 \%$ for the HFOR diet. The CON diet would be considered borderline deficient in peNDF (Mertens, 1997).

Based on the chemical composition and pef values of the 3 diets, observed differences in cow responses were presumably due to differences in starch content and digestibility, NDF content and digestibility, and physical effects of NDF sources. Therefore, the primary comparisons of interest were dietary starch content followed by source of NDF (forage versus nonforage fiber sources).

\section{DMI and Lactational Performance}

Dry matter intake, BW, and BCS of cows are presented in Table 6. Dry matter intake tended to increase for cows fed the CON diet $(28.1 \mathrm{~kg} / \mathrm{d})$ compared with the HFOR diet $(27.1 \mathrm{~kg} / \mathrm{d} ; P=0.06)$. Dry matter intake for cows fed the HNFFS diet was intermediate $(27.6 \mathrm{~kg} / \mathrm{d})$. In previous studies, partial replacement of corn meal with corn silage resulted in similar (Dann et al., 2008; Agle et al., 2010; Fredin et al., 2015) or lower DMI (Weiss et al., 2011). Decreased DMI for cows fed the HFOR diet compared with CON likely reflected the greater forage, forage NDF, and peNDF contents of the HFOR diet. In previous experiments, DMI was similar between normal- and reduced-starch diets in which grain was partially replaced with nonforage fiber sources (Bernard and McNeill, 1991; Ferraretto et al., 2011; Dann et al., 2014). Voelker and Allen (2003a) partially replaced high-moisture corn with 6,12 , or $24 \%$ beet pulp (as a \% of diet DM). Dry matter intake decreased linearly, primarily due to the large decrease in DMI at an inclusion of $24 \%$ beet pulp, whereas DMI were similar for cows fed diets containing 6 or $12 \%$ beet pulp (Voelker and Allen, 2003a). In the present experiment, there was a slight increase in peNDF content of the HNFFS diet compared with the CON diet. Furthermore, the inclusion of BMR and nonforage fiber sources in the HNFFS diet resulted in similar 24-h in vitro NDF digestibilities for the HNFFS diet compared with the CON diet (Table 3). The similarity in peNDF content and NDF digestibilities of the CON and HNFFS diets likely resulted in similar effects on ruminal distension and voluntary DMI (Allen, 2000). However, the rate of passage of NDF from the rumen may also be greater for the HNFFS diet due to the inclusion of nonforage fiber sources (Grant, 1997), thereby limiting the negative effects of ruminal distension on voluntary DMI for that diet. Intake of NDF was increased for the HFOR and 
Table 2. Chemical composition, in vitro digestibility, and fermentation analysis of ingredients used in diets $(\mathrm{n}=3 ;$ mean $\pm \mathrm{SE})$

\begin{tabular}{|c|c|c|c|c|c|c|c|c|}
\hline \multirow[b]{2}{*}{ Item } & \multirow{2}{*}{$\begin{array}{l}\text { Conventional } \\
\text { corn silage }\end{array}$} & \multirow{2}{*}{$\begin{array}{l}\text { Brown midrib } \\
\text { corn silage }\end{array}$} & \multirow[b]{2}{*}{ Hay crop silage } & \multirow[b]{2}{*}{ Corn meal } & \multirow[b]{2}{*}{ Pelleted beet pulp } & \multicolumn{3}{|c|}{ Grain mix ${ }^{1}$} \\
\hline & & & & & & $\mathrm{CON}$ & HFOR & HNFFS \\
\hline DM, \% & $31.4 \pm 0.4$ & $31.6 \pm 0.6$ & $31.2 \pm 0.6$ & $87.3 \pm 0.8$ & $88.6 \pm 0.3$ & $86.6 \pm 0.1$ & $86.6 \pm 0.0$ & $86.4 \pm 0.1$ \\
\hline $\mathrm{CP}, \%$ & $6.0 \pm 0.3$ & $7.4 \pm 0.1$ & $12.5 \pm 0.2$ & $8.8 \pm 0.0$ & $9.4 \pm 0.7$ & $36.2 \pm 0.4$ & $35.1 \pm 0.2$ & $30.8 \pm 0.5$ \\
\hline Soluble protein, \% CP & $60.1 \pm 1.5$ & $59.1 \pm 2.4$ & $63.1 \pm 1.1$ & $19.3 \pm 1.5$ & $26.0 \pm 3.1$ & $20.2 \pm 0.9$ & $22.4 \pm 1.0$ & $23.0 \pm 0.6$ \\
\hline Neutral detergent CP, \% & $0.8 \pm 0.0$ & $0.9 \pm 0.1$ & $1.8 \pm 0.1$ & $1.0 \pm 0.0$ & $4.0 \pm 0.4$ & $2.9 \pm 0.5$ & $2.8 \pm 0.2$ & $3.0 \pm 0.0$ \\
\hline $\mathrm{ADF}, \%$ & $25.6 \pm 0.9$ & $25.6 \pm 0.3$ & $40.5 \pm 0.3$ & $4.0 \pm 0.4$ & $24.0 \pm 1.2$ & $8.3 \pm 0.3$ & $8.9 \pm 0.1$ & $9.8 \pm 0.6$ \\
\hline $\mathrm{NDF}^{2} \%$ & $41.1 \pm 0.9$ & $41.4 \pm 0.3$ & $60.1 \pm 1.4$ & $11.0 \pm 0.2$ & $43.1 \pm 0.7$ & $17.6 \pm 0.6$ & $19.1 \pm 0.5$ & $21.5 \pm 0.3$ \\
\hline ADL, $\%$ & $2.8 \pm 0.1$ & $2.0 \pm 0.2$ & $5.8 \pm 0.2$ & $1.0 \pm 0.0$ & $3.0 \pm 0.3$ & $3.4 \pm 0.2$ & $3.2 \pm 0.1$ & $3.5 \pm 0.3$ \\
\hline Starch, \% & $36.9 \pm 0.7$ & $34.5 \pm 1.1$ & $2.1 \pm 0.4$ & $70.5 \pm 0.2$ & $1.0 \pm 0.4$ & $10.0 \pm 0.2$ & $9.1 \pm 0.3$ & $12.3 \pm 0.3$ \\
\hline $\mathrm{ESC},{ }^{3} \%$ & $1.2 \pm 0.0$ & $1.3 \pm 0.1$ & $2.6 \pm 0.1$ & $2.9 \pm 0.1$ & $10.5 \pm 1.2$ & $12.5 \pm 0.2$ & $12.1 \pm 0.1$ & $10.7 \pm 0.3$ \\
\hline $\mathrm{NFC}, 4 \%$ & $46.3 \pm 0.6$ & $43.1 \pm 1.0$ & $19.1 \pm 1.3$ & $75.6 \pm 0.2$ & $44.9 \pm 0.2$ & $30.6 \pm 0.5$ & $30.1 \pm 0.6$ & $33.0 \pm 0.9$ \\
\hline $\mathrm{NSC}^{5} \%$ & $38.1 \pm 0.7$ & $35.8 \pm 1.2$ & $4.7 \pm 0.3$ & $73.4 \pm 0.2$ & $11.5 \pm 1.6$ & $22.5 \pm 0.1$ & $21.2 \pm 0.4$ & $23.0 \pm 0.4$ \\
\hline Fat, $\%$ & $3.3 \pm 0.1$ & $2.8 \pm 0.2$ & $3.1 \pm 0.1$ & $4.0 \pm 0.2$ & $0.6 \pm 0.1$ & $5.0 \pm 0.2$ & $5.6 \pm 0.2$ & $5.6 \pm 0.1$ \\
\hline Ash, $\%$ & $3.97 \pm 0.09$ & $6.07 \pm 1.37$ & $6.90 \pm 0.15$ & $1.67 \pm 0.03$ & $6.03 \pm 0.09$ & $13.57 \pm 0.13$ & $12.97 \pm 0.18$ & $12.03 \pm 0.19$ \\
\hline $\mathrm{Ca}, \%$ & $0.26 \pm 0.02$ & $0.50 \pm 0.16$ & $0.71 \pm 0.03$ & $0.02 \pm 0.00$ & $0.88 \pm 0.06$ & $2.25 \pm 0.03$ & $2.20 \pm 0.10$ & $1.81 \pm 0.07$ \\
\hline $\mathrm{P}, \%$ & $0.14 \pm 0.01$ & $0.19 \pm 0.01$ & $0.24 \pm 0.01$ & $0.32 \pm 0.01$ & $0.11 \pm 0.02$ & $0.85 \pm 0.01$ & $0.86 \pm 0.00$ & $0.93 \pm 0.01$ \\
\hline $\mathrm{Mg}, \%$ & $0.13 \pm 0.01$ & $0.27 \pm 0.10$ & $0.27 \pm 0.00$ & $0.14 \pm 0.00$ & $0.32 \pm 0.01$ & $0.65 \pm 0.01$ & $0.64 \pm 0.01$ & $0.64 \pm 0.01$ \\
\hline $\mathrm{K}, \%$ & $0.60 \pm 0.02$ & $0.85 \pm 0.04$ & $2.23 \pm 0.11$ & $0.46 \pm 0.00$ & $0.62 \pm 0.05$ & $1.89 \pm 0.03$ & $1.83 \pm 0.02$ & $1.63 \pm 0.01$ \\
\hline S, $\%$ & $0.09 \pm 0.00$ & $0.12 \pm 0.01$ & $0.18 \pm 0.01$ & $0.11 \pm 0.00$ & $0.15 \pm 0.01$ & $0.48 \pm 0.01$ & $0.49 \pm 0.00$ & $0.48 \pm 0.01$ \\
\hline $\mathrm{Na}, \%$ & - & $0.01 \pm 0.00$ & $0.08 \pm 0.01$ & $0.01 \pm 0.00$ & $0.20 \pm 0.05$ & $1.17 \pm 0.01$ & $1.25 \pm 0.05$ & $1.13 \pm 0.01$ \\
\hline $\mathrm{Cl}, \%$ & $0.17 \pm 0.00$ & $0.22 \pm 0.01$ & $0.65 \pm 0.03$ & $0.05 \pm 0.00$ & $0.12 \pm 0.04$ & $0.95 \pm 0.01$ & $0.91 \pm 0.02$ & $0.87 \pm 0.02$ \\
\hline $\mathrm{Fe}, \mathrm{mg} / \mathrm{kg}$ & $205 \pm 19$ & $511 \pm 144$ & $173 \pm 13$ & $37 \pm 4$ & $610 \pm 110$ & $266 \pm 6$ & $260 \pm 6$ & $249 \pm 4$ \\
\hline $\mathrm{Cu}, \mathrm{mg} / \mathrm{kg}$ & $9 \pm 0$ & $19 \pm 4$ & $11 \pm 0$ & $2 \pm 0$ & $11 \pm 2$ & $67 \pm 3$ & $64 \pm 6$ & $49 \pm 3$ \\
\hline $\mathrm{Mn}, \mathrm{mg} / \mathrm{kg}$ & $32 \pm 1$ & $42 \pm 10$ & $97 \pm 12$ & $6 \pm 0$ & $52 \pm 1$ & $181 \pm 14$ & $174 \pm 3$ & $151 \pm 12$ \\
\hline $\mathrm{Zn}, \mathrm{mg} / \mathrm{kg}$ & $24 \pm 1$ & $28 \pm 2$ & $27 \pm 0$ & $27 \pm 1$ & $26 \pm 11$ & $211 \pm 24$ & $220 \pm 24$ & $183 \pm 20$ \\
\hline $\mathrm{NE}_{\mathrm{L}}$, Mcal $/ \mathrm{kg}$ & $1.62 \pm 0.03$ & $1.59 \pm 0.01$ & $1.29 \pm 0.01$ & $2.03 \pm 0.01$ & $1.59 \pm 0.03$ & $1.68 \pm 0.01$ & $1.71 \pm 0.01$ & $1.70 \pm 0.01$ \\
\hline 24-h NDF digestibility, ${ }^{6} \%$ of NDF & $39.8 \pm 0.8$ & $46.2 \pm 0.6$ & $47.0 \pm 0.2$ & - & - & - & - & - \\
\hline 2-h starch digestibility, $\%$ of starch & $33.7 \pm 1.0$ & $32.6 \pm 3.3$ & - & $27.8 \pm 0.7$ & - & $27.9 \pm 1.0$ & $25.8 \pm 3.0$ & $28.8 \pm 2.2$ \\
\hline 7-h starch digestibility, $\%$ of starch & $83.1 \pm 0.9$ & $81.7 \pm 1.1$ & - & $72.3 \pm 1.2$ & - & $73.1 \pm 1.8$ & $70.3 \pm 2.2$ & $74.3 \pm 0.9$ \\
\hline Lactic acid, \% & $4.9 \pm 0.1$ & $4.7 \pm 0.5$ & $5.8 \pm 0.3$ & - & - & - & - & - \\
\hline Acetic acid, \% & $2.6 \pm 0.2$ & $3.3 \pm 0.1$ & $2.1 \pm 0.3$ & - & - & - & - & - \\
\hline Propionic acid, \% & $0.2 \pm 0.0$ & $0.3 \pm 0.0$ & $0.2 \pm 0.0$ & - & - & - & - & - \\
\hline Butyric acid, \% & - & - & $0.1 \pm 0.0$ & - & - & - & - & - \\
\hline Total VFA, \% & $7.7 \pm 0.1$ & $8.3 \pm 0.6$ & $8.1 \pm 0.3$ & - & - & - & - & - \\
\hline Ammonia, $\%$ of $\mathrm{CP}$ & $14.3 \pm 0.4$ & $15.2 \pm 1.5$ & $12.4 \pm 0.1$ & - & - & - & - & - \\
\hline $\mathrm{pH}$ & $3.7 \pm 0.0$ & $3.9 \pm 0.1$ & $4.2 \pm 0.0$ & - & - & - & - & - \\
\hline
\end{tabular}

${ }^{1} \mathrm{CON}=$ normal-starch diet containing $50 \%$ forage; HFOR = low-starch diet containing $63 \%$ forage; HNFFS = low-starch diet containing $50 \%$ forage composed of forages simila to the control diet with corn meal and soybean meal partially replaced by nonforage fiber sources.

${ }^{2} \mathrm{NDF}$ with residual ash using $\alpha$-amylase without sodium sulfite.

${ }^{3} \mathrm{ESC}=$ ethanol-soluble carbohydrate.

${ }^{4} \mathrm{NFC}=100-[\mathrm{CP} \%+(\mathrm{NDF} \%-$ neutral detergent insoluble $\mathrm{CP} \%)+$ fat $\%+$ ash $\%] ; \mathrm{NRC}(2001)$.

${ }^{5} \mathrm{NSC}=$ starch + ESC.

${ }^{6} \mathrm{NDF}$ with residual ash using $\alpha$-amylase and sodium sulfite. 
Table 3. Chemical composition, in vitro digestibility, and fermentation analysis of diets varying in carbohydrate source $(\text { mean } \pm \mathrm{SE})^{1}$

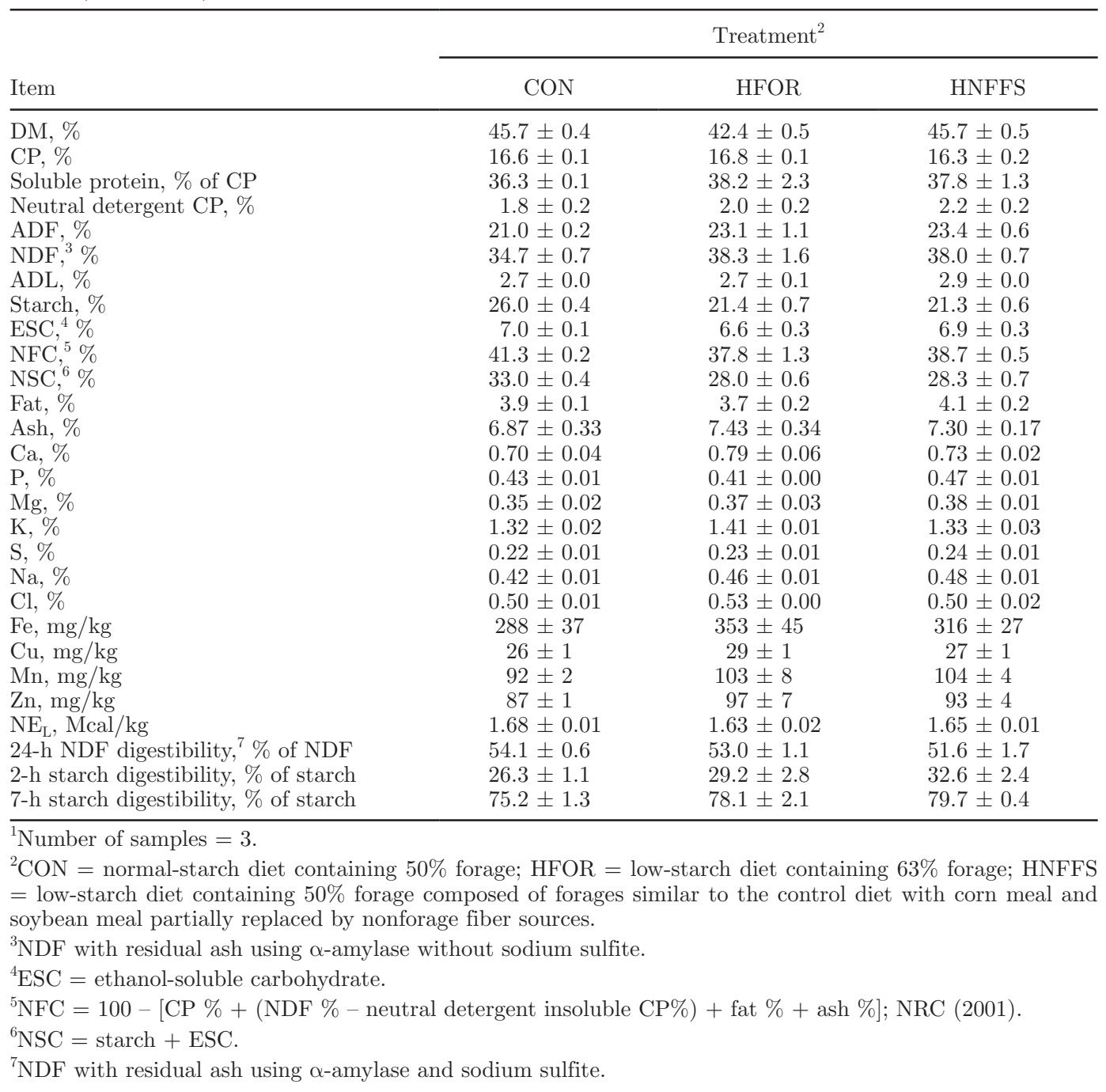

HNFFS diets compared with the CON $\operatorname{diet}(P=0.001)$, which reflected the greater NDF content of these diets (mean $=38.2 \%$ compared with $34.7 \%$ ), although the difference in NDF intake was only $0.8 \mathrm{~kg} /$ d. Physically effective NDF intake was least for the CON diet $(5.2$ $\mathrm{kg} / \mathrm{d})$, intermediate for the HNFFS diet $(6.1 \mathrm{~kg} / \mathrm{d})$, and greatest for the HFOR diet $(6.5 \mathrm{~kg} / \mathrm{d})$, reflecting the peNDF content of the diets $(P=0.001)$. Dry matter intake (as a \% of BW) was increased for cows fed the CON diet compared with cows fed the HFOR diet $(P=0.01)$, whereas NDF intake (as a $\%$ of $\mathrm{BW}$ ) was increased for cows fed the HFOR and HNFFS diets compared with cows fed the CON diet $(P=0.001)$, reflecting the NDF content of the diets.

Body weight was unaffected by diet, but BW change tended to increase for cows fed the HFOR diet compared with the HNFFS diet $(P<0.06)$. Body condition score did not differ among diets, although BCS change tended to decrease for cows fed the HFOR diet compared with the CON diet $(P<0.07)$. The tendency for differences in BW change can be partially explained by increased physical ruminal fill for cows fed the HFOR diet due to increased peNDF content (Mertens, 1997). However, the tendency for differences in BCS change is likely due to the lower $\mathrm{NE}_{\mathrm{L}}$ content of the HFOR diet compared with the CON diet (Table 3).

Lactational performance of cows is presented in Table 7. Milk yield was increased for cows fed the CON diet $(51.6 \mathrm{~kg} / \mathrm{d})$ compared with cows fed the HFOR $\operatorname{diet}(48.4 \mathrm{~kg} / \mathrm{d} ; P=0.01)$. Milk yield for cows fed the HNFFS diet was intermediate $(50.5 \mathrm{~kg} / \mathrm{d})$. The responses in milk yield mirrored the observed responses in DMI. In the literature, partial replacement of corn meal with corn silage has resulted in similar (Dann et 
Table 4. Particle size distribution of ingredients $($ mean $\pm \mathrm{SE})$

\begin{tabular}{|c|c|c|c|c|c|c|c|c|}
\hline \multirow[b]{2}{*}{ Item } & \multirow{2}{*}{$\begin{array}{l}\text { Conventional } \\
\text { corn silage }\end{array}$} & \multirow{2}{*}{$\begin{array}{l}\text { Brown midrib } \\
\text { corn silage }\end{array}$} & \multirow{2}{*}{$\begin{array}{l}\text { Hay crop } \\
\text { silage }\end{array}$} & \multirow{2}{*}{$\begin{array}{l}\text { Corn } \\
\text { meal }\end{array}$} & \multirow{2}{*}{$\begin{array}{l}\text { Pelleted } \\
\text { beet pulp }\end{array}$} & \multicolumn{3}{|c|}{ Grain $\operatorname{mix}^{1}$} \\
\hline & & & & & & $\mathrm{CON}$ & HFOR & HNFFS \\
\hline \multicolumn{9}{|c|}{ Particle size distribution of diet, ${ }^{2} \%$ as-fed } \\
\hline$>19.0 \mathrm{~mm}$ & $3.0 \pm 0.4$ & $4.9 \pm 0.4$ & $15.6 \pm 1$ & - & - & - & - & - \\
\hline 8.0 to $19.0 \mathrm{~mm}$ & $80.6 \pm 0.4$ & $76.0 \pm 0.7$ & $47.2 \pm 0.8$ & - & - & - & - & - \\
\hline$<8.0 \mathrm{~mm}$ & $16.4 \pm 0.6$ & $19.1 \pm 1.1$ & $37.2 \pm 0.3$ & - & - & - & - & - \\
\hline \multicolumn{9}{|c|}{ Particle size distribution, ${ }^{3} \%$ of DM } \\
\hline$>19.00 \mathrm{~mm}$ & $0.2 \pm 0.1$ & $0.3 \pm 0.2$ & $0.1 \pm 0.1$ & - & - & - & - & - \\
\hline 13.20 to $19.00 \mathrm{~mm}$ & $0.1 \pm 0.0$ & $1.1 \pm 0.4$ & $0.3 \pm 0.3$ & - & - & - & - & - \\
\hline 9.50 to $13.20 \mathrm{~mm}$ & $2.8 \pm 0.4$ & $3.4 \pm 0.2$ & $1.1 \pm 0.3$ & - & $0.6 \pm 0.5$ & - & - & - \\
\hline 6.70 to $9.50 \mathrm{~mm}$ & $15.2 \pm 0.4$ & $14.2 \pm 0.5$ & $2.0 \pm 0.3$ & - & $86.5 \pm 5.0$ & $0.1 \pm 0.1$ & - & - \\
\hline 4.75 to $6.70 \mathrm{~mm}$ & $21.3 \pm 0.3$ & $20.8 \pm 0.5$ & $3.0 \pm 0.5$ & $0.1 \pm 0.0$ & $3.4 \pm 0.6$ & $0.1 \pm 0.1$ & $0.2 \pm 0.0$ & $0.1 \pm 0.0$ \\
\hline 3.35 to $4.75 \mathrm{~mm}$ & $23.5 \pm 0.6$ & $24.1 \pm 1.1$ & $7.3 \pm 1.1$ & $0.4 \pm 0.2$ & $2.3 \pm 0.8$ & $0.2 \pm 0.1$ & $0.2 \pm 0.1$ & $0.3 \pm 0.1$ \\
\hline 2.36 to $3.35 \mathrm{~mm}$ & $15.7 \pm 0.5$ & $14.5 \pm 0.3$ & $13.9 \pm 0.3$ & $0.4 \pm 0.0$ & $2.3 \pm 1.1$ & $0.5 \pm 0.0$ & $0.6 \pm 0.1$ & $0.6 \pm 0.0$ \\
\hline 1.18 to $2.36 \mathrm{~mm}$ & $12.9 \pm 0.1$ & $12.7 \pm 0.5$ & $42.1 \pm 1.4$ & $13.5 \pm 1.8$ & $3.0 \pm 1.6$ & $17.4 \pm 0.2$ & $15.4 \pm 0.1$ & $15.1 \pm 0.3$ \\
\hline 0.60 to $1.18 \mathrm{~mm}$ & $4.7 \pm 0.0$ & $4.9 \pm 0.4$ & $22.9 \pm 0.4$ & $38.6 \pm 4.4$ & $1.0 \pm 0.7$ & $35.1 \pm 0.3$ & $33.6 \pm 0.1$ & $33.0 \pm 0.1$ \\
\hline 0.30 to $0.60 \mathrm{~mm}$ & $2.2 \pm 0.1$ & $2.5 \pm 0.2$ & $5.7 \pm 0.3$ & $25.0 \pm 10.3$ & $0.5 \pm 0.4$ & $33.2 \pm 0.1$ & $33.9 \pm 0.1$ & $35.5 \pm 0.2$ \\
\hline$<0.30 \mathrm{~mm}$ & $1.3 \pm 0.0$ & $1.4 \pm 0.2$ & $1.7 \pm 0.0$ & $21.9 \pm 4.4$ & $0.5 \pm 0.4$ & $13.3 \pm 0.5$ & $16.2 \pm 0.1$ & $15.5 \pm 0.2$ \\
\hline pef $^{4}$ & $0.92 \pm 0.00$ & $0.91 \pm 0.01$ & $0.70 \pm 0.01$ & $0.15 \pm 0.02$ & $0.98 \pm 0.01$ & $0.18 \pm 0.00$ & $0.16 \pm 0.00$ & $0.16 \pm 0.00$ \\
\hline peNDF, ${ }^{5} \%$ & $37.5 \pm 0.5$ & $36.2 \pm 1.0$ & $42.4 \pm 0.4$ & - & - & - & - & - \\
\hline
\end{tabular}

${ }^{1} \mathrm{CON}=$ normal-starch diet containing $50 \%$ forage HFOR = low-starch diet containing $63 \%$ forage; HNFFS = low-starch diet containing $50 \%$ forage composed of forages similar ${ }^{\mathrm{I}} \mathrm{CON}=$ normal-starch diet containing $50 \%$ forage; $\mathrm{HFOR}=$ low-starch diet containing $63 \%$ forage;
to the control diet with corn meal and soybean meal partially replaced by nonforage fiber sources.

${ }^{2}$ Measurements made with the Penn State Particle Separator (Lammers et al., 1996).

${ }^{3}$ Measurements made with the Ro-Tap shaker (W. S. Tyler Combustion Engineering Inc., Mentor, OH).

${ }^{4}$ pef $=$ physical effectiveness factor.

${ }^{5}$ peNDF $=$ physically effective NDF. 
Table 5. Particle size distribution of diets varying in carbohydrate source (mean $\pm \mathrm{SE}$ )

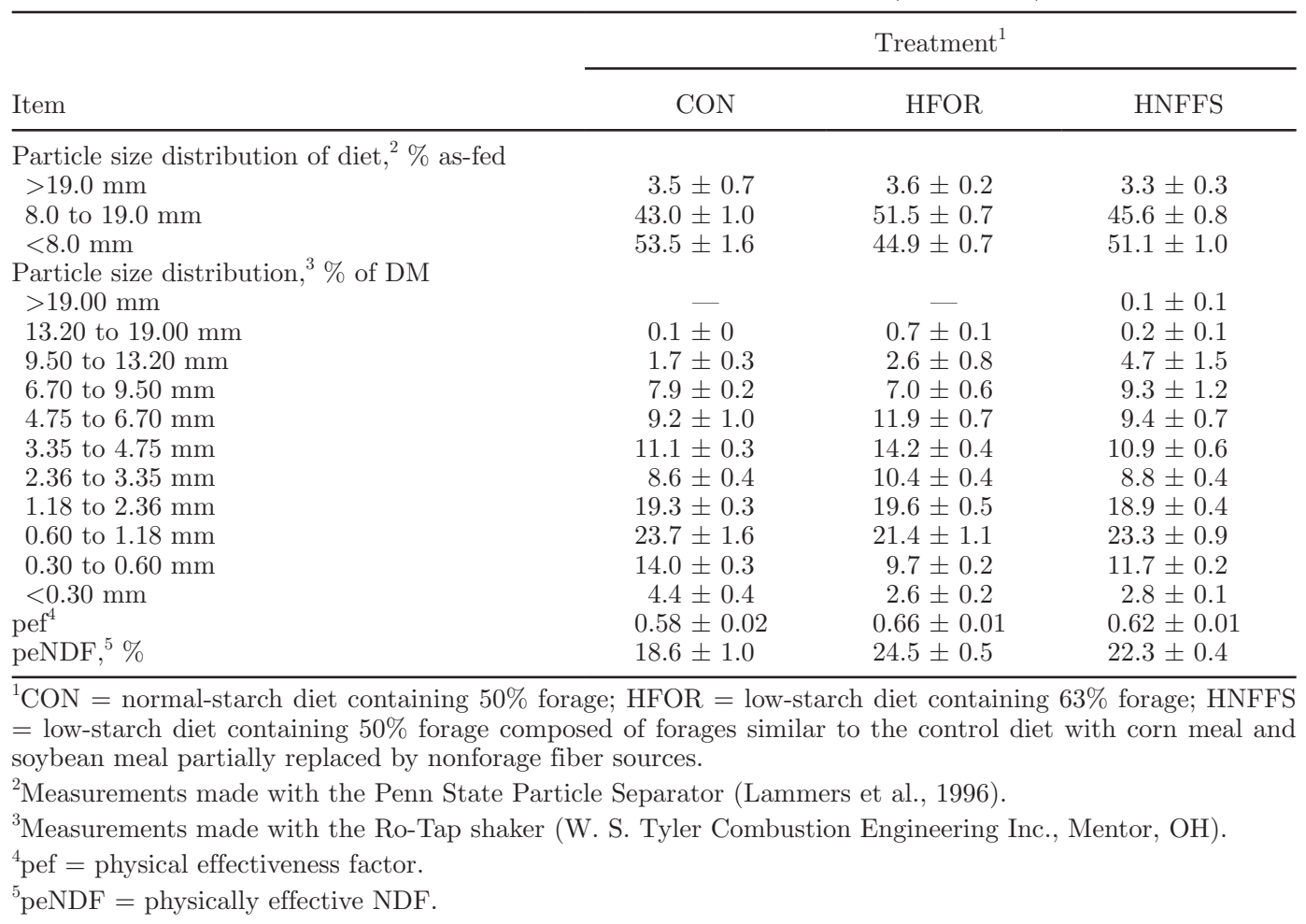

al., 2008; Fredin et al., 2015) or decreased milk yield (Agle et al., 2010; Weiss et al., 2011).

Milk fat content tended to increase for cows fed the HFOR diet (3.98\%) compared with cows fed the CON $\operatorname{diet}(3.66 \% ; P=0.06)$. Consequently, milk fat, $3.5 \%$ FCM, and SCM yields were unaffected by dietary treatment. In previous studies, milk fat content was similar when corn meal was partially replaced with corn silage
(Dann et al., 2008; Weiss et al., 2011; Fredin et al., 2015). Agle et al. (2010) reported an increase in milk fat content when corn meal was partially replaced with corn and alfalfa silages. The increase in milk fat content for cows fed the HFOR diet can be partially explained by the lower starch and higher peNDF contents compared with the CON diet. The positive relationship between peNDF and milk fat content was reported by

Table 6. Intake, BW, and BCS of cows fed diets varying in carbohydrate source

\begin{tabular}{|c|c|c|c|c|c|}
\hline \multirow[b]{2}{*}{ Item } & \multicolumn{3}{|c|}{ Treatment $^{1}$} & \multirow[b]{2}{*}{ SE } & \multirow[b]{2}{*}{$P$-value } \\
\hline & $\mathrm{CON}$ & HFOR & HNFFS & & \\
\hline DMI, $\mathrm{kg} / \mathrm{d}$ & $28.1^{\mathrm{x}}$ & $27.1^{\mathrm{y}}$ & $27.6^{\mathrm{xy}}$ & 0.8 & 0.08 \\
\hline NDF intake, $\mathrm{kg} / \mathrm{d}$ & $9.1^{\mathrm{b}}$ & $10.0^{\mathrm{a}}$ & $9.9^{\mathrm{a}}$ & 0.3 & 0.001 \\
\hline peNDF $^{2}$ intake, $\mathrm{kg} / \mathrm{d}$ & $5.2^{\mathrm{c}}$ & $6.5^{\mathrm{a}}$ & $6.1^{\mathrm{b}}$ & 0.2 & 0.001 \\
\hline DMI, $\%$ of BW & $3.85^{\mathrm{a}}$ & $3.67^{\mathrm{b}}$ & $3.75^{\mathrm{ab}}$ & 0.10 & 0.02 \\
\hline $\mathrm{NDF}$ intake, $\%$ of $\mathrm{BW}$ & $1.23^{\mathrm{b}}$ & $1.35^{\mathrm{a}}$ & $1.34^{\mathrm{a}}$ & 0.03 & 0.001 \\
\hline $\mathrm{BW}, \mathrm{kg}$ & 738 & 744 & 740 & 20 & 0.25 \\
\hline BW change, kg/21-d period & $16^{\mathrm{xy}}$ & $22^{\mathrm{x}}$ & $11^{\mathrm{y}}$ & 4 & 0.07 \\
\hline BCS & 2.77 & 2.80 & 2.79 & 0.06 & 0.76 \\
\hline BCS change, $\mathrm{kg} / 21-\mathrm{d}$ period & $0.02^{\mathrm{x}}$ & $-0.09^{\mathrm{y}}$ & $0.00^{\mathrm{xy}}$ & 0.03 & 0.06 \\
\hline
\end{tabular}


DANN ET AL.

Table 7. Lactation performance and feed conversion of cows fed diets varying in carbohydrate source

\begin{tabular}{|c|c|c|c|c|c|}
\hline \multirow[b]{2}{*}{ Item } & \multicolumn{3}{|c|}{ Treatment $^{1}$} & \multirow[b]{2}{*}{$\mathrm{SE}$} & \multirow[b]{2}{*}{$P$-value } \\
\hline & $\mathrm{CON}$ & HFOR & HNFFS & & \\
\hline \multicolumn{6}{|l|}{ Milk yield } \\
\hline Milk, $\mathrm{kg} / \mathrm{d}$ & $51.6^{\mathrm{a}}$ & $48.4^{\mathrm{b}}$ & $50.5^{\mathrm{ab}}$ & 2.3 & 0.01 \\
\hline $3.5 \% \mathrm{FCM}, \mathrm{kg} / \mathrm{d}$ & 52.6 & 51.7 & 52.4 & 2.0 & 0.78 \\
\hline $\mathrm{SCM}, \mathrm{kg} / \mathrm{d}$ & 49.0 & 47.3 & 48.5 & 1.9 & 0.40 \\
\hline \multicolumn{6}{|l|}{ Milk composition } \\
\hline Fat, $\%$ & $3.66^{\mathrm{y}}$ & $3.98^{\mathrm{x}}$ & $3.76^{\mathrm{xy}}$ & 0.17 & 0.07 \\
\hline Fat, $\mathrm{kg} / \mathrm{d}$ & 1.86 & 1.88 & 1.86 & 0.08 & 0.92 \\
\hline True protein, $\%$ & 3.10 & 3.07 & 3.08 & 0.06 & 0.47 \\
\hline True protein, $\mathrm{kg} / \mathrm{d}$ & $1.58^{\mathrm{a}}$ & $1.45^{\mathrm{b}}$ & $1.54^{\mathrm{ab}}$ & 0.05 & 0.01 \\
\hline Lactose, $\%$ & $4.83^{\mathrm{a}}$ & $4.76^{\mathrm{b}}$ & $4.80^{\mathrm{ab}}$ & 0.03 & 0.01 \\
\hline Lactose, $\mathrm{kg} / \mathrm{d}$ & $2.48^{\mathrm{a}}$ & $2.28^{\mathrm{b}}$ & $2.40^{\mathrm{ab}}$ & 0.11 & 0.02 \\
\hline SNF, $\%$ & $8.83^{\mathrm{a}}$ & $8.72^{\mathrm{b}}$ & $8.79^{\mathrm{ab}}$ & 0.08 & 0.05 \\
\hline $\mathrm{SNF}, \mathrm{kg} / \mathrm{d}$ & $4.52^{\mathrm{a}}$ & $4.17^{\mathrm{b}}$ & $4.40^{\mathrm{ab}}$ & 0.18 & 0.02 \\
\hline MUN, mg/dL & $11.2^{\mathrm{ab}}$ & $11.8^{\mathrm{a}}$ & $10.6^{\mathrm{b}}$ & 0.6 & 0.02 \\
\hline SCS & 2.35 & 2.69 & 2.66 & 0.62 & 0.64 \\
\hline \multicolumn{6}{|l|}{ Feed efficiency } \\
\hline Milk/DMI & 1.83 & 1.77 & 1.82 & 0.06 & 0.20 \\
\hline $3.5 \% \mathrm{FCM} / \mathrm{DMI}$ & 1.86 & 1.90 & 1.90 & 0.05 & 0.72 \\
\hline SCM/DMI & 1.73 & 1.74 & 1.75 & 0.04 & 0.88 \\
\hline Milk N efficiency, ${ }^{2} \%$ & $35.7^{\mathrm{a}}$ & $33.9^{\mathrm{b}}$ & $36.4^{\mathrm{a}}$ & 0.7 & 0.01 \\
\hline
\end{tabular}

Mertens (1997), and similar responses were observed by Dann et al. (2014) for cows fed diets containing similar forages and either 21 or $25 \%$ starch.

Protein and lactose yields and lactose content were increased for cows fed the CON diet compared with cows fed the HFOR diet $(P \leq 0.01)$. Data available in the literature are mixed in regards to the effects of replacing corn meal with corn silage or nonforage fiber sources on milk protein content and yield. Milk protein content and yield were similar when corn meal was partially replaced with corn silage (Dann et al., 2008; Weiss et al., 2011; Fredin et al., 2015). In contrast, milk protein yield was unaffected (Dann et al., 2014) or decreased (Ferraretto et al., 2011) when corn meal was partially replaced with nonforage fibers sources. Bernard and McNeill (1991) observed similar milk protein content and yields when partially replacing corn meal with wheat middlings. Voelker and Allen (2003a) also reported similar milk protein content and yields when partially replacing high-moisture corn with beet pulp.

Milk urea $\mathrm{N}$ was decreased for cows fed the HNFFS diet $(10.6 \mathrm{mg} / \mathrm{dL})$ compared with cows fed the HFOR $\operatorname{diet}(11.8 \mathrm{mg} / \mathrm{dL} ; P=0.02)$. Furthermore, milk N efficiency was improved for cows fed the CON and HNFFS diets compared with the HFOR $\operatorname{diet}(P \leq 0.001)$. Most nonforage fiber is relatively digestible compared with forage fiber (Bradford and Mullins, 2012). The increase in ruminal available energy from highly fermentable carbohydrate and digestible nonforage fiber sources can increase utilization of $\mathrm{NH}_{3}-\mathrm{N}$ by bacteria for improved efficiency of bacterial protein synthesis (Stern et al., 1994). Fredin et al. (2015) also reported lower MUN values for cows fed a normal-starch diet or a reducedstarch diet, in which corn meal was partially replaced with soybean hulls compared with a reduced-starch diet where corn meal was partially replaced with corn silage.

Feed efficiency ( $\mathrm{kg}$ of milk/ $\mathrm{kg}$ of DMI) was unaffected by dietary treatments. In previous literature, feed efficiency was reduced (Agle et al., 2010; Weiss et al., 2011) or similar (Dann et al., 2008; Fredin et al., 2015) when corn meal was partially replaced by corn silage. Feed efficiency was similar when corn meal was partially replaced by nonforage fiber sources (Dann et al., 2014) and tended to increase linearly when highmoisture corn was partially replaced with beet pulp (Voelker and Allen, 2003a). However, feed efficiency was decreased (Ferraretto et al., 2011; Akins et al., 2014) or tended to decrease (Gencoglu et al., 2010) in experiments conducted as randomized complete block designs lasting for $\geq 10 \mathrm{wk}$ when corn meal was partially replaced by nonforage fiber sources. These experiments indicate that continuous feeding trials lasting $\geq 10 \mathrm{wk}$ may be needed to accurately assess the feed efficiency 
Table 8. Behavior of cows fed diets varying in carbohydrate source

\begin{tabular}{|c|c|c|c|c|c|}
\hline \multirow[b]{2}{*}{ Item } & \multicolumn{3}{|c|}{ Treatment $^{1}$} & \multirow[b]{2}{*}{ SE } & \multirow[b]{2}{*}{$P$-value } \\
\hline & $\mathrm{CON}$ & HFOR & NFFS & & \\
\hline \multicolumn{6}{|l|}{ Chewing } \\
\hline $\min / \mathrm{d}$ & 766 & 793 & 776 & 18 & 0.25 \\
\hline $\mathrm{min} / \mathrm{kg}$ of $\mathrm{DM}$ & $26.9^{\mathrm{c}}$ & $29.4^{\mathrm{a}}$ & $28.1^{\mathrm{b}}$ & 0.9 & 0.001 \\
\hline $\mathrm{min} / \mathrm{kg}$ of NDF & $84.3^{\mathrm{a}}$ & $80.1^{\mathrm{b}}$ & $78.8^{\mathrm{b}}$ & 2.7 & 0.01 \\
\hline $\mathrm{min} / \mathrm{kg}$ of $\mathrm{peNDF}^{2}$ & $147.6^{\mathrm{a}}$ & $123.4^{\mathrm{b}}$ & $128.5^{\mathrm{b}}$ & 4.8 & 0.001 \\
\hline \multicolumn{6}{|l|}{ Eating } \\
\hline $\min / d$ & 236 & 238 & 234 & 12 & 0.90 \\
\hline $\min / \mathrm{kg}$ of $\mathrm{DM}$ & $8.3^{\mathrm{b}}$ & $9.0^{\mathrm{a}}$ & $8.5^{\mathrm{ab}}$ & 0.5 & 0.04 \\
\hline $\mathrm{min} / \mathrm{kg}$ of $\mathrm{NDF}$ & $26.0^{\mathrm{a}}$ & $24.0^{\mathrm{b}}$ & $23.9^{\mathrm{b}}$ & 1.4 & 0.01 \\
\hline $\mathrm{min} / \mathrm{kg}$ of peNDF & $45.4^{\mathrm{a}}$ & $37.2^{\mathrm{b}}$ & $38.9^{\mathrm{b}}$ & 2.4 & 0.001 \\
\hline \multicolumn{6}{|l|}{ Ruminating } \\
\hline $\mathrm{min} / \mathrm{d}$ & 530 & 554 & 541 & 12 & 0.13 \\
\hline $\min / \mathrm{kg}$ of $\mathrm{DM}$ & $18.7^{\mathrm{c}}$ & $20.7^{\mathrm{a}}$ & $19.7^{\mathrm{b}}$ & 0.6 & 0.001 \\
\hline $\mathrm{min} / \mathrm{kg}$ of NDF & $58.3^{\mathrm{a}}$ & $56.1^{\mathrm{ab}}$ & $54.8^{\mathrm{b}}$ & 1.7 & 0.01 \\
\hline $\mathrm{min} / \mathrm{kg}$ of peNDF & $102.1^{\mathrm{a}}$ & $86.4^{\mathrm{b}}$ & $89.3^{\mathrm{b}}$ & 3.1 & 0.001 \\
\hline
\end{tabular}

response of cows fed reduced-starch diets. In our experiment, BCS loss tended to be more pronounced in cows fed the HFOR diet compared with cows fed the CON diet (Table 6). The short-term periods in our experiment may have obscured potential decreases in feed efficiency for cows fed the HFOR diet if body condition was lost to maintain milk and fat yields. In an experiment with longer experimental periods, body condition will not be able to maintain milk and fat yields in the long term, resulting in reduced milk and components yields and feed efficiency.

\section{Chewing Responses}

Chewing behavior of cows is presented in Table 8 . Total chewing, eating, and ruminating time $(\mathrm{min} / \mathrm{d})$ were unaffected by dietary treatments. Rumination (min $/ \mathrm{kg}$ of DM) was greater for cows fed the HFOR diet, intermediate for cows fed the HNFFS diet, and least for cows fed the CON diet $(P=0.001)$, which reflects differences among the diets in peNDF (Table 4). However, when rumination time was expressed as a function of dietary NDF (min $/ \mathrm{kg}$ of NDF), rumination time was greatest for cows fed the CON diet and least for cows fed the HNFFS diet $(P=0.01)$. A substantial portion of the NDF in the HNFFS diet comprised nonforage fiber sources of NDF that elicit less chewing response than forage NDF (Mertens, 1997). Therefore, the CON diet should result in more rumination time per kilogram of NDF than the HNFFS diet. Similarly, Voelker and Allen (2003a) reported that rumination time per kilogram of NDF intake decreased linearly as high-moisture corn was replaced by beet pulp. Lower rumination time per kilogram of NDF for cows fed the HFOR diet may reflect the greater fragility of the BMR corn silage used in the HFOR diet versus the conventional corn silage used in the CON diet. Previous research has shown that BMR corn silage has greater fragility of NDF than conventional corn silage (Cotanch and Grant, 2008). Furthermore, the increased fragility of the BMR corn silage in the HFOR diet can reduce the amount of chewing and rumination time for cows (Taylor and Allen, 2005) and increase the passage rate of NDF out of the rumen (Oba and Allen, 2000).

\section{Ruminal Measures}

Ruminal measures and microbial $\mathrm{N}$ yield for cows are in Table 9. Mean, minimum, and maximum ruminal $\mathrm{pH}$ were unaffected by dietary treatments. For ruminal $\mathrm{pH}$, area less than 5.8 tended to be greater for cows fed the CON diet compared with the other 2 dietary treatments $(P=0.10)$, and time spent at $\mathrm{pH}<5.5$ tended to be greater for cows fed the CON diet compared with cows fed the HFOR $\operatorname{diet}(P=0.09)$. Subacute ruminal acidosis has been defined as depressed ruminal $\mathrm{pH}(5.0-5.5)$ for acute or chronic periods in duration (Krause and Oetzel, 2006). Ruminal $\mathrm{pH}<5.8$ for more than 5 to $6 \mathrm{~h}$ per day should also be avoided to minimize negative health effects caused by subacute ruminal acidosis (Zebeli et al., 2012). Ruminal pH results partially reflect the differences among diets in peNDF and likely 
increases in salivary buffer secretion during increased chewing per kilogram of DMI (Table 6). Furthermore, differences between the CON and HFOR diets in the source and amount of fermentable carbohydrate used, in addition to differences in particle size $<8.0 \mathrm{~mm}$ as measured by the Penn State Particle Separator (Table $5)$, likely resulted in an increased amount of rapidly degradable substrate and less structural carbohydrates for the CON diet (Zebeli et al., 2012). In previous experiments, mean ruminal $\mathrm{pH}$ was unaffected when corn meal was partially replaced by corn silage (Dann et al., 2008; Fredin et al., 2015). However, Agle et al. (2010) found that mean ruminal $\mathrm{pH}$ increased when corn meal was partially replaced by corn and alfalfa silages. Additionally, mean ruminal $\mathrm{pH}$ was unaffected when corn meal was replaced by nonforage fiber sources (Dann et al., 2014) or when high-moisture corn was replaced with beet pulp (Voelker and Allen, 2003b).

Total ruminal VFA concentrations were similar for all diets. Molar proportion of acetate tended to be greater for cows consuming the HFOR diet compared with cows on the CON diet $(P=0.07)$. However, ruminal propionate concentration and the ratio of ruminal acetate to propionate was unaffected by dietary treatments. Molar proportion of ruminal isobutyrate was reduced for cows fed the HNFFS diet compared with the CON and HFOR diets $(P=0.001)$. Ruminal acetate and isobutyrate concentrations (Dann et al., 2008) or molar proportions of ruminal acetate and isobutyrate (Fredin et al., 2015) were unaffected when corn meal was replaced with corn silage. Allen (1997) predicted that VFA production would be greatest, and $\mathrm{pH}$ least, for high-concentrate diets and that $\mathrm{pH}$ would be increased for high-forage diets or diets containing nonforage fiber sources in place of starch. We expected that the greatest concentration of ruminal VFA would be on the CON diet and the least with the HFOR diet. The HNFFS diet would be expected to have an intermediate ruminal VFA concentration because starch was replaced by highly fermentable NDF from nonforage fiber sources (Allen, 1997; Grant, 1997). The relatively small decrease in dietary starch for the reduced-starch diets compared with the CON diet (mean $=4.7$-percentage-unit decrease in starch) may not have been a large enough reduction to elicit an increase in ruminal $\mathrm{pH}$.

Ruminal $\mathrm{NH}_{3}-\mathrm{N}$ concentrations were unaffected by dietary treatments (Table 9). There was an interaction for treatment and time for ruminal $\mathrm{NH}_{3}-\mathrm{N}$ concentrations $(P=0.02$; Figure 1$)$. Cows fed the HNFFS diet had lower ruminal $\mathrm{NH}_{3}-\mathrm{N}$ concentrations at 720,960 , and 1,200 min after feeding compared with the other 2 dietary treatments. Stern et al. (1994) reported a lower $\mathrm{NH}_{3}-\mathrm{N}$ concentration in continuous culture for diets containing beet pulp in place of corn grain. This effect could be due to lesser protein degradation or in-

Table 9. Ruminal measures and estimated microbial $\mathrm{N}$ yield of cows fed diets varying in carbohydrate source

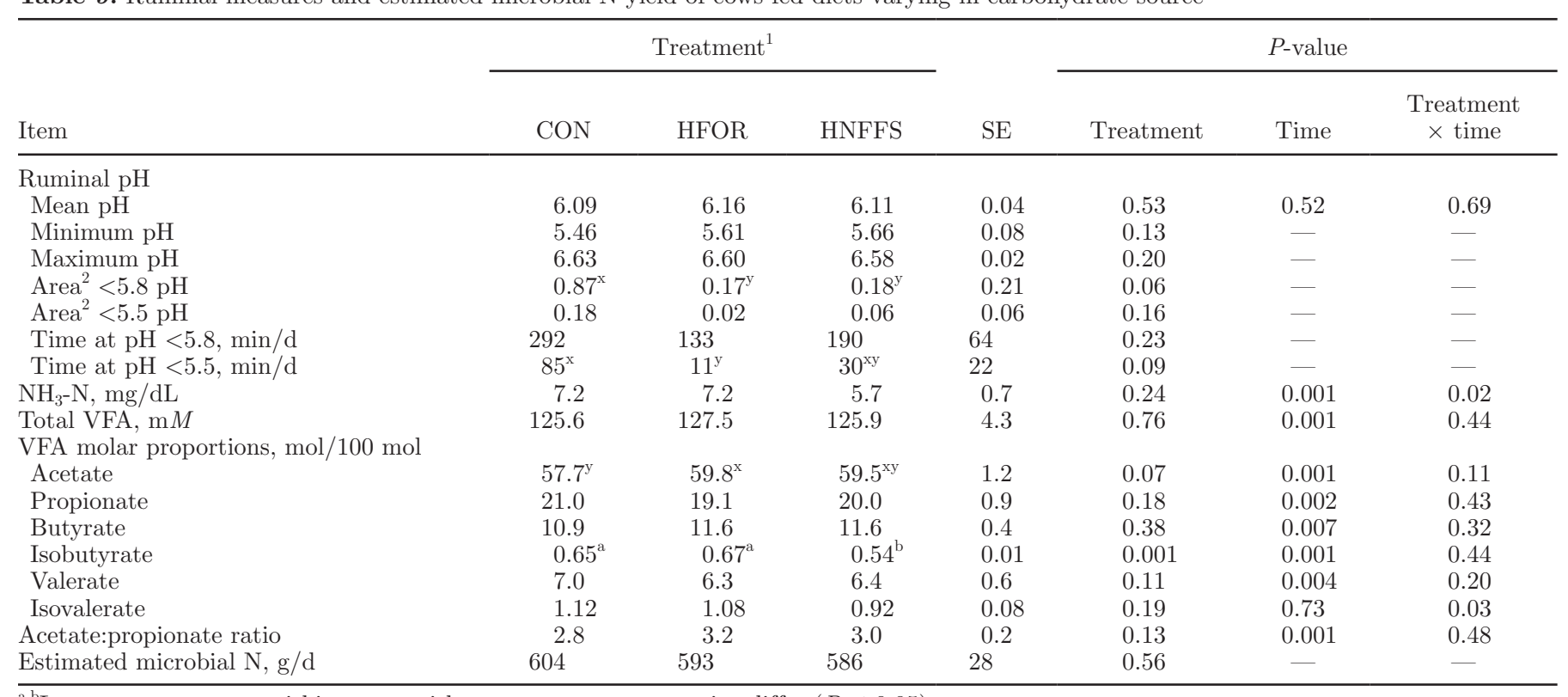

${ }^{\mathrm{a}, \mathrm{b}}$ Least squares means within a row without a common superscript differ $(P \leq 0.05)$.

${ }^{x, y}$ Least squares means within a row without a common superscript differ $(P \leq 0.10)$.

${ }^{1} \mathrm{CON}=$ normal-starch diet containing $50 \%$ forage; HFOR $=$ low-starch diet containing $63 \%$ forage; HNFFS $=$ low-starch diet containing $50 \%$ forage composed of forages similar to the control diet with corn meal and soybean meal partially replaced by nonforage fiber sources.

${ }^{2}$ Area $<5.8$ or $5.5=$ area under the curve below pH 5.8 or 5.5 . 


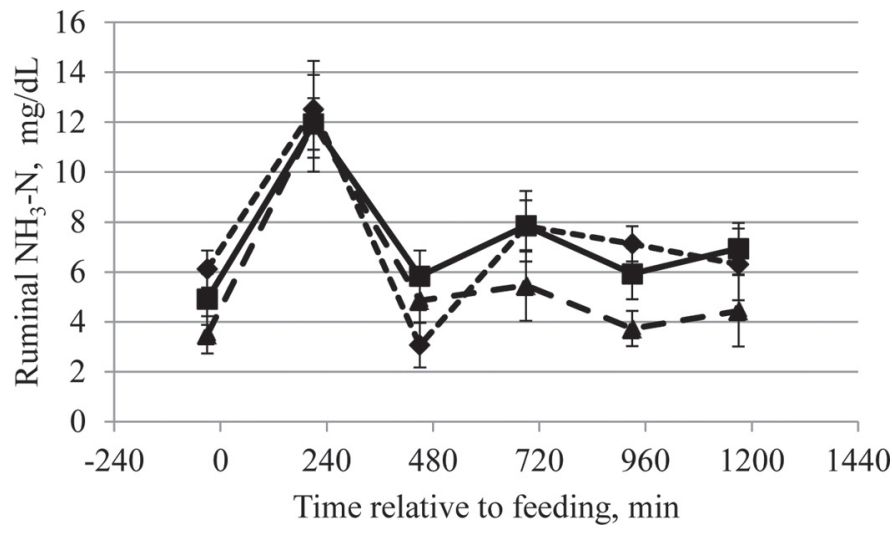

Figure 1. Ruminal $\mathrm{NH}_{3}-\mathrm{N}(\mathrm{mg} / \mathrm{dL})$ concentration for lactating cows fed diets varying in carbohydrate source. CON $(\bullet)=$ normalstarch diet containing 50\% forage; HFOR (ם) = low-starch diet containing $63 \%$ forage; HNFFS $(\boldsymbol{\Delta})=$ low-starch diet containing $50 \%$ forage comprising forages similar to the control diet with corn meal and soybean meal partially replaced by nonforage fiber sources. Treatment effect: $P=0.24$; time effect: $P<0.001$; treatment by time interaction: $P=0.02 ; \mathrm{SE}=1.9$

creased microbial protein synthesis with the beet pulp diets (Stern et al., 1994). Although beet pulp was not the sole nonforage fiber source in the HNFFS diet, the lower ruminal $\mathrm{NH}_{3}-\mathrm{N}$ concentrations for cows fed the HNFFS diet are in agreement with results for MUN concentration (Table 7). Elevated ruminal $\mathrm{NH}_{3}-\mathrm{N}$ concentrations have been previously reported when corn meal was replaced by corn silage (Agle et al., 2010; Fredin et al., 2015). Microbial N yield was unaffected by diet and averaged $594 \mathrm{~g} / \mathrm{d}$ across all dietary treatments. Dann et al. (2014) reported high microbial N yield in cows fed similar diets.

\section{CONCLUSIONS}

When nonforage fiber sources partially replaced corn meal in the diet, DMI and milk yield were unaffected. If corn meal was partially replaced with BMR corn silage, then DMI and milk yield were decreased compared with the CON diet. However, the HFOR diet increased milk fat content. Consequently, FCM and SCM were unaffected by dietary treatments. Reducedstarch diets resulted in similar short-term efficiency of milk production compared with the CON diet. Based on the amount of time ruminal $\mathrm{pH}$ was $<5.5$, the $\mathrm{CON}$ diet was associated with compromised ruminal $\mathrm{pH}$ compared with the reduced-starch diets, and long-term ruminal health implications may favor increased inclusion of higher forage or nonforage fiber sources in diets. In a short-term study, reduced-starch diets maintained FCM, SCM, and feed efficiency in high-producing midlactation Holstein cows.

\section{ACKNOWLEDGMENTS}

The authors thank the Zen-Noh National Federation of Agricultural Cooperative Associations (Tokyo, Japan) for funding the experiment and the research and farm staff of the William H. Miner Agricultural Research Institute (Chazy, NY) for care and feeding of the cows.

\section{REFERENCES}

Agle, M., A. N. Hristov, S. Zaman, C. Schneider, P. M. Ndegwa, and V. K. Vaddella. 2010. Effect of dietary concentrate on rumen fermentation, digestibility, and nitrogen losses in dairy cows. J. Dairy Sci. 93:4211-4222.

Akins, M. S., K. L. Perfield, H. B. Green, S. J. Bertics, and R. D. Shaver. 2014. Effect of monensin in lactating dairy cow diets at 2 starch concentrations. J. Dairy Sci. 97:917-929.

Allen, M. S. 1997. Relationship between fermentation acid production in the rumen and the requirement for physically effective fiber. J. Dairy Sci. 80:1447-1462.

Allen, M. S. 2000. Effects of diet on short-term regulation of feed intake by lactating dairy cattle. J. Dairy Sci. 83:1598-1624.

AOAC International. 2012. Official Methods of Analysis. 19th ed. AOAC International, Arlington, VA.

Bauer, M. L., D. W. Herold, R. A. Britton, R. A. Stock, T. J. Klopfenstein, and D. A. Yates. 1995. Efficacy of laidlomycin propionate to reduce ruminal acidosis in cattle. J. Anim. Sci. 73:3445-3454.

Bernard, J. K., and W. W. McNeill. 1991. Effect of high fiber energy supplements on nutrient digestibility and milk production of lactating dairy cows. J. Dairy Sci. 74:991-995.

Bradford, B. J., and C. R. Mullins. 2012. Invited review: Strategies for promoting productivity and health of dairy cattle by feeding nonforage fiber sources. J. Dairy Sci. 95:4735-4746.

Chaney, A. L., and E. P. Marbach. 1962. Modified reagents for determination of urea and ammonia. Clin. Chem. 8:130-132.

Chen, X. B., F. D. Hovell, E. R. Ørskov, and D. S. Brown. 1990. Excretion of purine derivatives by ruminants: Effect of exogenous nucleic acid supply on purine derivative excretion by sheep. Br. J. Nutr. 63:131-142.

Cotanch, K., and R. J. Grant. 2008. Fiber digestibility and forage fragility in dairy cattle. Pages 77-84 in Proceedings of the Cornell Nutrition Conference for Feed Manufacturers, Syracuse, NY. Cornell Univ., Ithaca, NY.

Dann, H. M., R. J. Grant, K. W. Cotanch, E. D. Thomas, C. S. Ballard, and R. Rice. 2008. Comparison of brown midrib sorghumsudangrass with corn silage on lactational performance and nutrient digestibility in Holstein dairy cows. J. Dairy Sci. 91:663-672.

Dann, H. M., H. A. Tucker, K. W. Cotanch, P. D. Krawczel, C. S. Mooney, R. J. Grant, and T. Eguchi. 2014. Evaluation of lower starch diets for lactating Holstein dairy cows. J. Dairy Sci. 97:7151-7161.

Dohme, F., T. J. DeVries, and K. A. Beauchemin. 2008. Repeated ruminal acidosis challenges in lactating dairy cows at high and low risk for developing acidosis: Ruminal pH. J. Dairy Sci. 91:35543567.

Ferguson, J. D., D. T. Galligan, and N. Thomsen. 1994. Principal descriptors of body condition score in Holstein cows. J. Dairy Sci. 77:2695-2703.

Ferraretto, L. F., R. D. Shaver, M. Espineira, H. Gencoglu, and S. J. Bertics. 2011. Influence of a reduced-starch diet with or without exogenous amylase on lactation performance by dairy cows. J. Dairy Sci. 94:1490-1499.

Fredin, S. M., M. S. Akins, L. F. Ferraretto, and R. D. Shaver. 2015. Effects of corn-based diet starch content and neutral detergent fiber source on lactation performance, digestibility, and bacterial protein flow in dairy cows. J. Dairy Sci. 98:554-565. 
Gencoglu, H., R. D. Shaver, W. Steinberg, J. Ensink, L. F. Ferraretto, S. J. Bertics, J. C. Lopes, and M. S. Akins. 2010. Effect of feeding a reduced-starch diet with or without amylase addition on lactation performance in dairy cows. J. Dairy Sci. 93:723-732.

Goering, H. K., and P. J. Van Soest. 1970. Forage Fiber Analysis: Apparatus, Reagents, Procedures, and Some Applications. Agric. Handbook No. 379. Agricultural Research Service, USDA, Washington, DC.

Grant, R. J. 1997. Interactions among forages and nonforage fiber sources. J. Dairy Sci. 80:1438-1446.

Hall, M. B. 2009. Analysis of starch, including maltooligosaccharides, in animal feeds: A comparison of methods and a recommended method for AOAC collaborative study. J. AOAC Int. 92:42-49.

Hall, M. B., W. H. Hoover, J. P. Jennings, and T. K. Miller Webster. 1999. A method for partitioning neutral detergent-soluble carbohydrates. J. Sci. Food Agric. 79:2079-2086.

Krause, K. M., and G. R. Oetzel. 2006. Understanding and preventing subacute ruminal acidosis in dairy herds: A review. Anim. Feed Sci. Technol. 126:215-236.

Krishnamoorthy, U., T. V. Muscato, C. J. Sniffen, and P. J. Van Soest. 1982. Nitrogen fractions in selected feedstuffs. J. Dairy Sci. 65:217-225.

Lammers, B. P., D. R. Buckmaster, and A. J. Heinrichs. 1996. A simple method for the analysis of particle sizes of forage and total mixed rations. J. Dairy Sci. 79:922-928.

Mertens, D. R. 1997. Creating a system for meeting the fiber requirements of dairy cows. J. Dairy Sci. 80:1463-1481.

Mertens, D. R. 2002. Determination of starch in large particles. RoTap shaker method. Revised April 2002. US Dairy Forage Research Center, Madison, WI.

NRC. 2001. Nutrient Requirements of Dairy Cattle. 7th rev. ed. Natl. Acad. Press, Washington, DC.

Oba, M., and M. S. Allen. 2000. Effects of brown midrib 3 mutation in corn silage on productivity of dairy cows fed two concentrations of dietary neutral detergent fiber: 3. Digestibility and microbial efficiency. J. Dairy Sci. 83:1350-1358.

Penner, G. B., K. A. Beauchemin, and T. Mutsvangwa. 2006. An evaluation of the accuracy and precision of a stand-alone submersible continuous ruminal $\mathrm{pH}$ measurement system. J. Dairy Sci. 89:2132-2140

Richards, C. J., F. F. Peterson, R. A. Britton, R. A. Stock, and C. R. Krehbiel. 1995. In vitro starch disappearance procedure modifications. Anim. Feed Sci. Technol. 55:35-45.
Shook, G. E. 1993. Genetic improvement of mastitis through selection on somatic cell count. Vet. Clin. North Am. Food Anim. Pract. 9:563-581.

Stern, M. D., G. A. Varga, J. H. Clark, J. L. Firkens, J. T. Huber, and D. L. Palmquist. 1994. Symposium: Metabolic relationships in supply of nutrients for milk protein synthesis. J. Dairy Sci. $77: 2762-2786$.

Taylor, C. C., and M. S. Allen. 2005. Corn grain endosperm type and brown midrib 3 corn silage: Feeding behavior and milk yield of lactating cows. J. Dairy Sci. 88:1425-1433.

Tyrrell, H. F., and J. T. Reid. 1965. Prediction of the energy value of cow's milk. J. Dairy Sci. 48:1215-1223.

USDA-NASS (National Agricultural Statistics Service). 2014. Prices received for corn by month. Accessed Aug. 18, 2014. http://www. nass.usda.gov/Charts_and_Maps/Agricultural_Prices/pricecn. asp.

Valadares, R. F. D., G. A. Broderick, S. C. Valadares Filho, and M. K. Clayton. 1999. Effect of replacing alfalfa silage with high moisture corn on ruminal protein synthesis estimated from excretion of total purine derivatives. J. Dairy Sci. 82:2686-2696.

Van Soest, P. J., J. B. Robertson, and B. A. Lewis. 1991. Methods for dietary fiber, neutral detergent fiber, and nonstarch polysaccharides in relation to animal nutrition. J. Dairy Sci. 74:3583-3597.

Voelker, J. A., and M. S. Allen. 2003a. Pelleted beet pulp substituted for high-moisture corn: 1. Effects on feed intake, chewing behavior, and milk production of lactating dairy cows. J. Dairy Sci $86: 3542-3552$

Voelker, J. A., and M. S. Allen. 2003b. Pelleted beet pulp substituted for high-moisture corn: 3. Effects on ruminal fermentation, $\mathrm{pH}$ and microbial protein efficiency in lactating dairy cows. J. Dairy Sci. 86:3562-3570.

Weiss, W. P., W. Steinberg, and M. A. Engstrom. 2011. Milk production and nutrient digestibility by dairy cows when fed exogenous amylase with coarsely ground dry corn. J. Dairy Sci. 94:24922499.

Zebeli, Q., J. R. Aschenbach, M. Tafaj, J. Boguhn, B. N. Ametaj, and W. Drochner. 2012. Invited review: Role of physically effective fiber and estimation of dietary fiber adequacy in high-producing dairy cattle. J. Dairy Sci. 95:1041-1056. 